\title{
Copernicus Mission - Advancement in Land Monitoring
}

\author{
Nikola Kranjčíć ${ }^{*}$ and Bojan Đurin ${ }^{2}$ \\ ${ }^{1}$ Department of Geotechnical Engineering, University of Zagreb, Croatia \\ ${ }^{2}$ Department of Civil Engineering, University North, Croatia
}

Submission: December 06, 2019; Published: December 13, 2019

*Corresponding author: Nikola Kranjčić, Department of Geotechnics, Faculty of Geotechnical Engineering, University of Zagreb, Croatia

Abstract

Since 2014 European Union is launching Sentinel satellites under mission Copernicus in order to observe and monitor planet Earth and its environment. Sentinel-1, Sentinel-2 and Sentinel-3 are operable their collected data can be evaluated, while other satellites are intended to launch in upcoming years. In this paper we are reflecting on launched and to be launched satellites and their potential and advancement in land monitoring.

Keywords: Copernicus; Sentinels; Land monitoring; Advancement

\section{Introduction}

The first orbital satellite image of Earth was taken in 1959. Since that day huge advancement was made in spatial resolution of satellite imagery and in various types of data available. Landsat satellite mission for a long period of time posed a most stable and most used datasets. However, European Union has proposed satellite mission called Copernicus. Today, Copernicus is Earth Observation Programme, coordinated by European Commission, and it offers information services based on satellite Earth Observation and in situ data. Currently, there are Sentinel-1, Sentinel-2 and Sentinel-3 in orbit. Sentinel-1 provides all-weather, 24 hours radar imagery for land and ocean services. Sentinel-2 provides high-resolution optical imagery for land services, soil and water cover, inland waters, vegetation imagery, coastal areas etc. Also, it produces information for emergency services. Sentinel-3 offers high-accuracy optical, radar and altimetry data for marine and land services. It measures sea-surface topography, sea and land surface temperature, ocean color and land color. Possibilities and advancements of first three missions of Copernicus are proven in many scientific articles. Sentinel 1 was used in many different areas of expertise such as monitoring dam vulnerability, mapping ice in lakes, differentiating early and late transplanted rice, monitoring phenology and classification of coniferous forests, detection and monitoring of tunneling induced ground movements, monitoring hydro temporal variability, etc. Sentinel 2 was used for different area and expertise mapping, fusion with other satellite imagery and improving different areas, such as minerals mapping, vegetation health mapping, burnt areas mapping etc. Biggest advancement in Sentinel 2 is in improved spatial resolution of visible and infrared spectra. Sentinel 3 data is relatively new, but advancement is seen already in observing marine environment, monitoring snow cover and in exploring biophysical parameters and canopy fluorescence. Sentinel 4 will provide data for atmospheric composition monitoring in order to monitor key air quality trace gases and aerosols over Europe. Sentinel 5 will provide accurate measurements of key atmospheric constituents such as ozone, Sulphur dioxide, carbon monoxide, nitrogen dioxide, methane, formaldehyde and aerosol properties. Sentinel 6 will ensure high accuracy altimetry for measuring global sea-surface height for oceanography and for climate studies. Since first three missions, Sentinel 1, Sentinel 2, Sentinel 3, has shown great advancement in Earth observation missions. Many of scientific papers has been published and large of number of authors agreed on huge advancement and potential of Sentinel missions. Data from first three missions has also been used in development of different business. Therefore, without any doubt authors of this opinion declare that other three missions, Sentinel 4, Sentinel 5 and Sentinel 6, will also show potential and advancement in Earth observation. All together Copernicus mission will benefit all, scientific, business and private community. 
DOI: 10.19080/IJESNR.2019.23.556101

Your next submission with Juniper Publishers will reach you the below assets

- Quality Editorial service

- Swift Peer Review

- Reprints availability

- E-prints Service

- Manuscript Podcast for convenient understanding

- Global attainment for your research

- Manuscript accessibility in different formats (Pdf, E-pub, Full Text, Audio)

- Unceasing customer service

Track the below URL for one-step submission https://juniperpublishers.com/online-submission.php 